\title{
The Effects of Mixed Vitamins, Minerals, Fatty Acids and Amino Acids Supplementation into Drinking Water on Broiler Chickens' Performance and Carcass Traits
}

\author{
Sadarman $^{1}$, Rizki Arisandi ${ }^{1}$, Abdul Hamid ${ }^{1}$, Eniza Saleh ${ }^{1}$, Wieda N. H. Zain ${ }^{1}$, Muhammad M. Sholikin ${ }^{2}$, Tri R. \\ Prihambodo $^{2}$, Rakhmad P. Harahap ${ }^{3}$, Rondius Solfaine ${ }^{4}$, Ahmad Sofyan ${ }^{5}$ and Agung Irawan ${ }^{6 * *}$ \\ ${ }^{1}$ Animal Science Study Program, Faculty of Agriculture and Animal Science, State Islamic University of Sultan Syarif Kasim, Pekanbaru, Riau 28293, Indonesia \\ ${ }^{2}$ Graduate School of Nutrition and Feed Science, Faculty of Animal Science, IPB University, Bogor, Indonesia \\ ${ }^{3}$ Animal Science Study Program, Faculty of Agriculture, Universitas Tanjungpura, Pontianak 78115, Indonesia \\ ${ }^{4}$ Department of Pathology, Faculty of Veterinary Medicine, Universitas Wijaya Kusuma Surabaya, Surabaya 60225, Indonesia \\ ${ }^{5}$ Research Unit for Natural Products Technology (BPTBA), Indonesia Institute of Sciences, Yogyakarta, Indonesia \\ ${ }^{6}$ Vocational School, Universitas Sebelas Maret, Surakarta 57126, Indonesia \\ *Corresponding author's Email: sadarman@ uin-suska.ac.id ; ORCID: 0000-0002-9632-8478 \\ ***orresponding author's Email: a.irawan@staff.uns.ac.id ; ORCID: 0000-0003-1179-0469
}

Received: 02 Jan. 2021

Accepted: 16 Feb. 2021

\begin{abstract}
The present study was conducted to evaluate the effects of different levels of the feed supplement containing minerals, fatty acids, vitamins, and amino acids added to drinking water on broiler chickens' performance and carcass traits. A total of 100 one-day-old Cobb 707 (mean weight $46.7 \mathrm{~g}$ ) were randomly assigned into four treatments, including control group (C), C $+2.25 \mathrm{ml} / \mathrm{L}$ Viterna Plus (V1), C $+2.50 \mathrm{ml} / \mathrm{L}$ Viterna Plus (V2), and C + $2.75 \mathrm{ml} / \mathrm{L}$ Viterna Plus (V3). Each treatment group contained 5 replicates of 5 birds in each ( 25 birds per treatment). Birds were maintained for 28 days. The results suggested that feed supplement at $2.50 \mathrm{ml} / \mathrm{L}$ could successfully improve final body weight, performance index, and carcass weight $(\mathrm{P}<0.05)$. Concurrently, the treatment also reduced the percentage of abdominal fat $(\mathrm{P}<0.05)$. In the current study, there were no significant differences in terms of feed intake and feed conversion ratio among treatment groups $(\mathrm{P}>0.05)$. In conclusion, the incorporation of commercial feed supplement containing mixed of minerals, vitamins, and amino acids at $2.50 \mathrm{ml} / \mathrm{L}$ into drinking water improved the overall performance of the broiler chickens.
\end{abstract}

Keywords: Broiler chicken, Carcass, Feed supplement, Tropics, Viterna plus.

\section{INTRODUCTION}

Optimal nutrient formula and high-quality raw materials are two key factors to support the fast-growing rates of broiler chickens. In the tropics, high ambient temperature and humidity are the major constraints for maximum broilers' productivity (Yousaf et al., 2019), which directly impact their health, welfare, and performance (Zhou et al., 2020). Under heat stress conditions, broilers use more energy to dissipate body temperature as a result of high metabolic rates, thus leading to energy deficiency or energy imbalance for maintenance and production function (Bin et al., 2017). A large number of studies have indicated that high environmental temperature impaired nutrient absorption and utilization, broiler growth, feed efficiency, and considerable economic losses (Zhou et al., 2019). In addition, it is also known to induce several metabolic disorders in modern broilers' genetics (Olubodun et al., 2015; Yousaf et al., 2019).

In such conditions, nutrient modification by providing instant nutrients and additives are essential to support the normal biological function and metabolic activities of broiler chickens. Among additives, vitamins and amino acids are the most widely used both for preventing heat stress and improving productivity. Amino acids supplementation is important to compensate dietary crude protein (CP) since it is known that dietary $\mathrm{CP}$ produces higher heat production which can compromise the broiler hyperthermic condition (Gonzalez-Esquerra and Leeson, 2006; Santos et al., 2020). In addition, studies reported that broiler chickens with heat stress experienced a reduction in the levels of plasma ascorbic acid, $\alpha$ tocopherol, and ascorbic acid (Saiz del Barrio et al., 2020).

To cite this paper: Sadarman, Arisandi R, Hamid A, Saleh E, Zain WNH, Sholikin MM, Prihambodo TR, Harahap RP, Solfaine R, Sofyan A, and Irawan A (2021). The Effects of Mixed Vitamins, Minerals, Fatty Acids and Amino Acids Supplementation into Drinking Water on Broiler Chickens' Performance and Carcass Traits. J. World Poult. Res., 11 (1): 47-52. DOI: https://dx.doi.org/10.36380/jwpr.2021.7 
Therefore, it is also important to increase the density of dietary vitamins, such as vitamin $\mathrm{A}, \mathrm{E}$, and $\mathrm{C}$ above the minimum requirement to support the antioxidant status of the animals (El-Senousey et al., 2018; Gan et al., 2020).

Viterna Plus is a commercial additive containing complete minerals, vitamins, amino acids, and fatty acids (aspartic acid, glutamic acid) in a single product which is produced from natural substances (Supartini, 2008). Those essential nutrients can be directly absorbed in the small intestine, allowing them to be directly used by broiler chickens for metabolism. A previous study revealed that supplementing Viterna Plus via drinking water improved weight gain and feed conversion ratio (FCR, Sutomo et al., 2015). It can be supplemented via drinking water or feed. Accordingly, the present experiment aimed to evaluate the effects of different levels of supplementation with Viterna Plus via drinking water on the performance and carcass traits of broiler chickens.

\section{MATERIALS AND METHODS}

\section{Ethical approval}

All procedures performed in this study involving broiler chickens were approved by the Ethical Committee of Faculty of Agriculture and Animal Sciences, Universitas Islam Negeri Syarif Kasim, Riau, Indonesia.

\section{Animals, diets, and experimental design}

The present experiment was conducted at the experimental farm of the Faculty of Agriculture and Animal Science, State Islamic University of Sultan Syarif Kasim, Riau, Indonesia. A total of 100 one-day-old (DOC) Cobb 707 (mixed sex and average weight of 46.7 gram) were randomly assigned to one of the following four treatment groups: control group (C), $\mathrm{C}+2.25 \mathrm{ml} / \mathrm{L}$ Viterna Plus (V1), C $+2.50 \mathrm{ml} / \mathrm{L}$ Viterna Plus (V2), and C $+2.75 \mathrm{ml} / \mathrm{L}$ Viterna Plus (V3). Each treatment group contained five replicates of five chickens (25 birds per treatment). The chickens had a similar initial weight of 46.7 g. In the current study, all birds received a similar diet purchased from a commercial retailer, and the diets were prepared according to two feeding phases of starter (1-20 days, in crumble form) and finisher (21-28 days, in pellet form). The chemical composition of the diet was analyzed according to AOAC (2005) for crude protein $(\mathrm{CP})$, ether extract (EE), crude fiber $(\mathrm{CF})$, calcium $(\mathrm{Ca})$, phosphorus (P), and ash, and Rostagno (2011) for metabolizable energy (ME) calculation. The nutritional composition of each diet (commercial feed) is presented in Table 1.
Broiler chickens were maintained on an open house system equipped with typical Indonesian farmer litter. They had free access to feed and drinking water. Starter feed was provided in a crumble form, while finisher diet was given in a pellet form. In addition, water was provided in a five-litter chicken water jar. Lighting and other rearing management were in according to Cobb 700 manual guide. Viterna Plus was obtained commercially. The product contained vitamins ( $\mathrm{C}$ and $\mathrm{B}$ complexes), minerals (N, P, K, Ca, Mg, Na, Cl, S, Fe, Zn, Cu, Mn, I, $\mathrm{Co}, \mathrm{Mb}, \mathrm{Se}, \mathrm{Cr}, \mathrm{F}$ ), fatty acids (aspartic acid and glutamic acid), and amino acids (Lysine, Methionine, Leucine, Isoleucine, Valine, Arginine, Threonine, Tryptophan, Tyrocine, Serine, Phenylalanine; PT. Natural Nusantara).

Table 1. The nutritional composition of starter and finisher diets of broiler chickens used for this experiment

\begin{tabular}{lcc}
\hline \multirow{2}{*}{ Nutrient composition } & \multicolumn{2}{c}{ Feeding phase } \\
\cline { 2 - 3 } & $\begin{array}{c}\text { Starter } \\
(\mathbf{1 - 2 0} \text { days })\end{array}$ & $\begin{array}{c}\text { Finisher } \\
(\mathbf{2 1}-\mathbf{2 8} \text { days })\end{array}$ \\
\hline Metabolizable energy (ME, kcal/kg) & 2781 & 2910 \\
Crude protein (CP, \%) & 23.5 & 20.5 \\
Crude fiber (CF, \%) & 5.0 & 5.0 \\
Ether extract (EE, \%) & 5.0 & 5.0 \\
Ca (\%) & 0.9 & 0.9 \\
Total Phosphorus (\%) & 0.6 & 0.6 \\
Ash (\%) & 7.0 & 7.0 \\
Lysine (\%) & 1.30 & 1.10 \\
\hline
\end{tabular}

\section{Sampling and measurements}

Feed intake (FI), body weight (BW), and FCR were recorded on weekly basis. Body weight was determined by weighing all of the birds in each replicated. The FCR was calculated as cumulative FI/ final BW. Mortality (if any) was recorded daily. In addition, index performance was calculated according to European Production Efficiency Factor (EPEF) at 28 days with the formula of (average daily gain $(\mathrm{g}) \times(100-\%$ mortality $) /(\mathrm{FCR} \times 10)$. Broilers were slaughtered after 28 days to determine the carcass yield, percentage, and other body components.

\section{Statistical analysis}

This study was arranged according to the completely randomized design of ANOVA with four experimental treatments and five replicates of each. Raw data were initially subjected to an outlier test. Data with more than $\sim 2$ of standard deviations of the mean were defined as outlier thus were excluded from the analysis. All data were subjected to ANOVA, followed by Duncan's multiple range test to compare means among the treatments. Significant was declared when $\mathrm{P}<0.05$. The statistical analysis was conducted using IBM SPSS statistics version 20. 


\section{RESULTS AND DISCUSSION}

\section{Broiler chickens' performance}

The performance of broiler chickens as affected by levels of Viterna Plus is presented in Table 2. Throughout the experiment, there was no mortality and culling recorded, indicating that all birds were healthy and comfortable with the house condition. Dietary Viterna Plus in any levels did not affect FI and FCR (P > 0.05). However, it had a significant effect on body weight gain (BWG), water intake, and performance index reflected from EPEF value $(\mathrm{P}<0.05)$. Final BW was higher for the chickens that received $2.50 \mathrm{ml} / \mathrm{L}$ of Viterna plus, compared to the control group ( $\mathrm{P}<0.05)$. However, supplementing at 2.25 and $2.75 \mathrm{ml} / \mathrm{L}$ Viterna Plus did not influence the BWG. In line with BWG, the EPEF value for V2 also indicated the highest achievement than any other treatments (Table 2). This result suggested that Viterna Plus containing essential nutrients is beneficial for broiler chickens in terms of improving their overall performance.

Generally speaking, incorporating vitamins and minerals mixed with additive into the diet or drinking water can alleviate the heat stress on broiler chickens. As the experimental chickens did not experience any heat stress indications, the effect of feed supplement in this study can not be fully expected. The major findings were the improvement in broiler performance by adding feed supplement, compared to the control group. This result can be primarily related to higher micro and macronutrient density imported from the supplement as it contains minerals, vitamins, and amino acids which are essential for broilers' growth (Saiz del Barrio et al., 2020). Considering the composition of the supplement used, there may be a synergistic effect among electrolytes such as $\mathrm{Na}$, $\mathrm{K}, \mathrm{Cl}$. Previous studies reported that supplementation multiple micronutrients on broilers' diet and drinking water improved the average daily gain (ADG) and FCR (Panda et al., 2008; Imik et al., 2013; Saiz del Barrio et al., 2020). Furthermore, vitamins also play a crucial role in maintaining broilers' health and immune system. It was demonstrated that supplementation of vitamin A at 15.000 IU successfully improved BW, FCR, and carcass yield of broiler chickens exposed to heat stress (Kucuk et al., 2003) while ascorbic acid (vitamin C) was also known to promote a higher carcass percentage and quality (Kutlu, 2001), ameliorate the bacterial challenge, and improve the structure of cecal microbiota and intestinal health (Gan et al., 2020). Moreover, mixed of vitamins A, D, E, and B complex was also reported to improve the immune system under heat stress (Lin et al., 2006). The primary role of vitamins can be related to lowering the oxidative stress that is susceptible for broiler chickens in a hot climate (Akbarian et al., 2016).

Additionally, the beneficial effects of Viterna Plus could also be attributed to the role of amino acids. Amino acids are known to have specific and multiple biological functions primarily for growth, maintenance, reproduction as well as defense mechanisms in the immune regulatory pathways (Trevisi et al., 2015). Indeed, the specific effect of each amino acid could not be elucidated since the amounts of amino acids were not quantified individually in the present study. However, there are a large number of explanations in the literature that amino acids are involved almost in all metabolic pathways including maintaining the balance of free radicals, diminish cell damage, and body protein synthesis (Bin et al., 2017). In an appropriate amount, the effect would be likely as an additive similar to the product used in the current study, the percentage of each individual amino acids was low.

Viterna Plus in the current study significantly increased water intake (Table 2). A higher water intake in some cases was detrimental because it may increase the risk of wet litter, and then increase the risk of other problems, such as skin dermatitis, bacterial infection, footpad lesions, which increases the potential risk of rejection at slaughterhouses (Shepherd and Fairchild, 2010). As wet litter was not observed in the present study, the amount of water intake was assumed in the normal range.

Table 2. Performance of the broiler chickens affected by different levels of Viterna Plus

\begin{tabular}{lccccc}
\hline \multirow{2}{*}{ Performance parameters } & \multicolumn{4}{c}{ Treatment groups } \\
\cline { 2 - 6 } & $\mathbf{C}$ & $\mathbf{V 1}$ & $\mathbf{V 2}$ & V3 & p-value \\
\hline Water intake (L) & $4.76 \pm 0.46^{\mathrm{b}}$ & $5.11 \pm 0.44^{\mathrm{ab}}$ & $5.52 \pm 0.16^{\mathrm{a}}$ & $4.89 \pm 0,50^{\mathrm{b}}$ & 0.048 \\
Feed intake (g) & $1.99 \pm 0.07$ & $2.00 \pm 0.06$ & $2.04 \pm 0.05$ & $1.99 \pm 0.39$ & 0.552 \\
Body weight gain (kg) & $1.11 \pm 0.04^{\mathrm{b}}$ & $1.14 \pm 0.04^{\mathrm{ab}}$ & $1.19 \pm 0.01^{\mathrm{a}}$ & $1.11 \pm 0.04 \mathrm{~b}$ & 0.011 \\
Feed conversion & $1.80 \pm 0.07$ & $1.75 \pm 0.04$ & $1.71 \pm 0.04$ & $1.80 \pm 0.08$ & 0.111 \\
Mortality (\%) & 0 & 0 & 0 & 0 & - \\
EPEF & $220 \pm 14.5^{\mathrm{b}}$ & $233 \pm 12.6^{\mathrm{ab}}$ & $249 \pm 6.11^{\mathrm{a}}$ & $222 \pm 18.1^{\mathrm{b}}$ & 0.017 \\
\hline
\end{tabular}

EPEF: European Production Efficiency Factor; Different superscripts on the same line show significant differences (p < 0.05), C: Control, V1: $2.25 \mathrm{ml} / \mathrm{L}$ Viterna Plus, V2: 2.50 ml/L Viterna Plus, V3: 2.75 ml/L Viterna Plus 
Table 3. Carcass traits of broiler chickens affected by different levels of Viterna Plus

\begin{tabular}{lccccc}
\hline & \multicolumn{3}{c}{ Treatment groups } \\
\cline { 2 - 6 } Variables & $\mathbf{C}$ & $\mathbf{V 1}$ & $\mathbf{V 2}$ & V3 & p-value \\
\hline Carcass weight (g) & $793 \pm 33.8^{\mathrm{bc}}$ & $843 \pm 44.6^{\mathrm{ab}}$ & $906 \pm 71.7^{\mathrm{a}}$ & $752 \pm 52.1^{\mathrm{c}}$ & 0.002 \\
Carcass (\%) & $68.8 \pm 4.45$ & $71.0 \pm 5.86$ & $73.2 \pm 6.19$ & $64.9 \pm 4.68$ & 0.125 \\
Abdominal fat (g) & $28.4 \pm 5.85^{\mathrm{ab}}$ & $27.2 \pm 1.39^{\mathrm{ab}}$ & $24.1 \pm 2.05^{\mathrm{a}}$ & $30.4 \pm 1.33^{\mathrm{b}}$ & 0.049 \\
Abdominal fat (\%) & $2.45 \pm 0.47^{\mathrm{b}}$ & $2.29 \pm 0.17^{\mathrm{ab}}$ & $1.95 \pm 0.19^{\mathrm{a}}$ & $2.62 \pm 0.17^{\mathrm{b}}$ & 0.011
\end{tabular}

Different superscripts on the same line show significant differences (p < 0.05), C: Control, V1: 2.25 ml/L Viterna Plus, V2: 2.50 ml/L Viterna Plus, V3: 2.75 $\mathrm{ml} / \mathrm{L}$ Viterna Plus

\section{Carcass traits}

As indicated in Table 3, carcass weight was higher for chickens receiving $2.50 \mathrm{ml} / \mathrm{L}$ of the treatment (V2), which had $14.3 \%$ higher than that of the control group $(\mathrm{P}<0.05)$. This result was in line with the $\mathrm{BW}$ of the $\mathrm{V} 2$ (Table 2) in which concurrently produced a higher carcass portion. Interestingly, the group of V3 treatment had the lowest carcass weight among others. However, there was no difference among treatments regarding carcass percentage.

The carcass of broiler chickens ranged around 60$65 \%$ of their BW at the end of harvest time (Ahmad et al., 2020). The percentage of the carcass can be related to the type of chickens reared, length or duration of maintenance, amount and quality of feed paid for during the maintenance and management. One of the maintenance management that needs to be known is feeding management. Errors in implementation, which will have an impact on the mobilization of feed nutrients into abdominal fat. Overall results of the present study suggested that adding more essential nutrients, such as amino acids with constant basal CP and energy improved their balance as well as productive energy released from the diet. This can be elucidated by the fact that amino acids promote body protein components.

Concurrently, higher carcass weight in the V2 also resulted in significantly lower abdominal fat and fat percentage in comparison with any other treatments ( $\mathrm{P}<$ 0.05; Table 3). Fat deposition is attributable to minimal heat and is enhanced by increasing body temperatures. Apparently, the productive advantage from supplement improvements under the present terms of experimentation did not relieve heat formation to the extent that muscle formation could benefit. Moreover, Rahmatnejad and Saki (2015) suggested that fat deposits in body tissues are a form of excess energy in poultry. This means that chickens consuming higher energy above their requirement are likely to deposit higher body fat. However, feed containing high energy (metabolizable energy, ME) will increase the cost or production resulting in higher feed price as well as feed cost. In addition to fat deposits from excess feed energy, Redka et al. (2019) suggested that fat deposits in the body of broilers can also come from triglycerides. Triglycerides in the tissues of broilers and poultry are generally a component that comes from the feed by $95 \%$, and only $5 \%$ are synthesized alone in the liver.

According to Lohakare et al. (2004), the addition of vitamin $\mathrm{C}$ in feed at $10-20 \mathrm{ppm}$ resulted in $2.70-2.94 \%$ abdominal fat of live weight. A decrease in the percentage of broilers' abdominal fat, consuming drinking water with the addition of $2.50 \%$ commercial supplements, may affect the potentiality of commercial supplements to improve the balance of microorganisms in broilers' intestines, and furthermore improve nutrient absorption. The factors to reduce the percentage of broilers' abdominal fat are considered to be the nutritional content of the feed, age, and type or strain of broilers (Henry et al., 2001).

\section{CONCLUSION}

In conclusion, the incorporation of commercial feed supplements containing mixed of minerals, vitamins, and amino acids at the dose of $2.50 \mathrm{ml} / \mathrm{L}$ into the drinking water improved the overall performance of broiler chickens reflected from higher final body weight and carcass weight. Concurrently, the treatment also reduced the percentage of abdominal fat relative to body weight which is beneficial for carcass quality. Further research evaluating economic feasibility is therefore demanding.

\section{DECLARATIONS}

\section{Acknowledgments}

Authors thank anonymous reviewers for giving valuable comments to improve the manuscript. 


\section{Competing interests}

Authors have no competing interests to declare.

\section{Authors' contribution}

Sadarman, Abdul Hamid, Eniza Saleh, and Wieda N. H. Zain conceptualized supervised the experiments, Rizki Arisandi did the investigation and data collection, Muhammad M. Sholikin, Tri R. Prihambodo, and Rakhmad P. Harahap did the data curation and statistical analysis, Rondius Solfaine, Ahmad Sofyan, and Agung Irawan were responsible for reviewing and revising the manuscript. All authors checked and approved the statistical results and final proof of the article.

\section{REFERENCES}

Ahmad I, Qaisrani SN, Azam F, Pasha TN, Bibi F, Naveed S, and Murtaza S (2020). Interactive effects of threonine levels and protein source on growth performance and carcass traits, gut morphology, ileal digestibility of protein and amino acids, and immunity in broilers. Poultry Science, 99(1): 280-289. DOI: https://doi.org/10.3382/ps/pez488.

Akbarian A, Michiels J, Degroote J, Majdeddin M, Golian A, and De Smet S (2016). Association between heat stress and oxidative stress in poultry; mitochondrial dysfunction and dietary interventions with phytochemicals. Journal of Animal Science and Biotechnology, 7(1): 37. DOI: https://doi.org/10.1186/s40104-016-0097-5.

Bin P, Huang R, and Zhou X (2017). Oxidation resistance of the sulfur amino acids: Methionine and cysteine. Biomedical Research International, Article ID 9584932. DOI: https://doi.org/10.1155/2017/9584932.

El-Senousey HK, Chen B, Wang JY, Atta AM, Mohamed FR, and Nie QH (2018). Effects of dietary Vitamin C, Vitamin E, and alphalipoic acid supplementation on the antioxidant defense system and immune-related gene expression in broilers exposed to oxidative stress by dexamethasone. Poultry Science, 97(1): 30-38. DOI: https://doi.org/10.3382/ps/pex298.

Gan L, Fan H, Mahmood T, and Guo Y (2020). Dietary supplementation with vitamin $\mathrm{C}$ ameliorates the adverse effects of Salmonella Enteritidis-challenge in broilers by shaping intestinal microbiota. $\begin{array}{llll}\text { Poultry Science, 99(7): 3663-3674. DOI: } & \end{array}$ https://doi.org/10.1016/j.psj.2020.03.062.

Gonzalez-Esquerra R, and Leeson S (2006). Physiological and metabolic responses of broilers to heat stress - Implications for protein and amino acid nutrition. World's Poultry Science Journal, 62: 282-295. DOI: https://doi.org/10.1079/WPS200597

Henry MH, Pesti GM, Bakalli R, Lee J, Toledo RT, Eitenmiller RR, and Phillips RD (2001). The performance of broiler chicks fed diets containing extruded cottonseed meal supplemented with lysine. $\begin{array}{llll}\text { Poultry Science, } & \text { 80(6): } & 762-768 . & \end{array}$ https://doi.org/10.1093/ps/80.6.762.

Imik H, Kaynar O, Ozkanlar S, Gumus R, Polat H, and Ozkanlar Y (2013). Effects of vitamin $\mathrm{C}$ and $\alpha$-lipoid acid dietary supplementations on metabolic adaptation of broilers to heat stress. Revista Medica Veterinaria (Toulouse), 164(2): 52-59. DOI: https://www.revmedvet.com/artdes-us.php?id=15896

Kucuk O, Sahin N, and Sahin K (2003). Supplemental Zinc And Vitamin A Can Alleviate Negative Effects Of Heat Stress In Broiler Chickens. Biological Trace Element Research, 94(3): 225-235. DOI: https://doi.org/10.1385/BTER:94:3:225
Kutlu HR (2001). Influences of wet feeding and supplementation with ascorbic acid on performance and carcass composition of broiler chicks exposed to a high ambient temperature. Archives of Animal Nutrition, $\quad 54(2)$ : $127-139 . \quad$ DOI: https://doi.org/10.1080/17450390109381972

Lin H, Jiao H C, Buyse J, and Decuypere E (2006). Strategies for preventing heat stress in poultry. World's Poultry Science Journal, 62(1): 71-86. DOI: https://doi.org/10.1079/WPS200585

Lohakare JD, Chae BJ, and Hahn TW (2004). Effects of feeding methods (water vs. feed) of vitamin $\mathrm{C}$ on growth performance and carcass characteristics in broiler chickens. Asian-Australasian Journal of Animal Science, 17(8): 1112-1117. DOI: https://doi.org/10.5713/ajas.2004.1112.

Olubodun JO, Zulkifli I, Farjam AS, Hair-Bejo M, and Kasim A (2015). Glutamine and glutamic acid supplementation enhances performance of broiler chickens under the hot and humid tropical condition. Italian Journal of Animal Science, 14(1): 25-29. DOI: https://doi.org/10.4081/ijas.2015.3263.

Panda AK, Ramarao SV, Raju MVLN, and Chatterjee RN (2008). Effect of dietary supplementation with vitamins $\mathrm{e}$ and $\mathrm{C}$ on production performance, immune responses and antioxidant status of White Leghorn layers under tropical summer conditions. British Poultry Science, $49(5)$ : $592-599 . \quad$ DOI: https://doi.org/10.1080/00071660802337233.

Rahmatnejad E, and Saki AA (2015). Effect of dietary fibres on small intestine histomorphology and lipid metabolism in young broiler chickens. Journal of Animal Physiology and Animal Nutrition, 100: 665-672. DOI: https://doi.org/10.1111/jpn.12422

Redka A, Bomko V, Slomchynskyi M, Cherniavskyi O, and Babenko S (2019). Digestibility of feed nutrients, nutrient excretion and nutrient retention in broilers under consumption of combined feed with sulfate and zinc-mixed ligand complex. Ukrainian Journal of Ecology, 9(3): 156-161. Available at: https://www.ujecology.com/abstract/digestibility-of-feed-nutrientsnutrient-excretion-and-nutrient-retention-in-broilers-underconsumption-of-combined-feed-44506.html

Saiz del Barrio A, Mansilla WD, Navarro-Villa A, Mica JH, Smeets JH, den Hartog LA, and García-Ruiz AI (2020). Effect of mineral and vitamin $\mathrm{C}$ mix on growth performance and blood corticosterone concentrations in heat-stressed broilers. Journal of Applied Poultry $\begin{array}{lll}\text { Research, } & 29(1) \text { : 23-33. }\end{array}$ https://doi.org/10.1016/j.japr.2019.11.001.

Santos TTD, Baal SCS, Lee SA, Bedford M, Fávaro Jr C, and Silva AVF (2020). Immune profile of broilers between hatch and 9 days of age fed diets with different betaine and fibre concentrations. Journal of Worlds Poultry Research, 10 (2): 397-406. DOI: https://dx.doi.org/10.36380/jwpr.2020.47

Shepherd EM, and Fairchild BD (2010). Footpad dermatitis in poultry. Poultry Science, 89: 2043-2051. DOI: https://doi.org/10.3382/ps.2010-00770

Supartini N (2008). Efek suplement (Viterna) terhadap penampilan produksi ayam pedaging fase finisher. Buana Sains, 8(2): 137-140. Available https://jurnal.unitri.ac.id/index.php/buanasains/article/viewFile/272/ $\underline{273}$

Sutomo B, Ihsan MN, and Hamiyanti AA (2015). Pengaruh pemberian feed supplement viterna pada air minum terhadap penampilan ayam pedaging, $\quad 16(2)$ : 25-29. https://doi.org/10.3975/cagsb.2017.02.15.

Trevisi P, Corrent E, Mazzoni M, Messori S, Priori D Gherpelli Y, Simongiovanni A, and Bosi P (2015). Effect of added dietary threonine on growth performance, health, immunity and gastrointestinal function of weaning pigs with differing genetic susceptibility to Escherichia coli infection and challenged with E. coli K88ac. Journal of Animal Physiology and Animal Nutrition, 99: 511-520. DOI: https://doi.org/10.1111/jpn.12216 
Yousaf A, Tabasam MS, Rajput N, Shahnawaz R, Rajpar S, Jamil T, and Mushtaq M (2019). Prevalence of ascaridia galli in different broiler poultry farms of potohar region of rawalpindi-Pakistan. Journal of Dairy, Veterinary and Animal Research, 14(1): 71-73. DOI: https://doi.org/10.15406/jdvar.2019.08.00245.

Zhou Y, Li X, Zhang MH, and Feng JH (2019). Effect of relative humidity at either acute or chronic moderate temperature on growth performance and droppings' corticosterone metabolites of broilers.
Journal of Integrated Agriciculture, 18(1): 152-159. DOI: https://doi.org/10.1016/S2095-3119(18)62049-0.

Zhou Y, Liu H, and Zhang M (2020). Analysis of the metabolic pathways affected by hot-Humid or dry climate based on fecal metabolomics coupled with serum metabolic changes in broiler chickens. Poultry Science, 99(11): 5526-5546. DOI: https://doi.org/10.1016/j.psj.2020.07.039. 